Available online at GSC Online Press Directory

GSC Biological and Pharmaceutical Sciences

e-ISSN: 2581-3250, CODEN (USA): GBPSC2

Journal homepage: https://www.gsconlinepress.com/journals/gscbps

(RESEARCH ARTICLE)

\title{
Antimicrobial, antioxidant activities and toxicity on Cavia porcellus of Dialium angolense Welw. Ex Oliv, a traditional medicinal plant from Bagira in Eastern of DR Congo
}

\author{
Bashige Chiribagula V 1, 2, 3, ${ }^{*}$, Bakari Amuri S ${ }^{1}$, Okusa Ndjolo Philippe ${ }^{2}$, Kahumba Byanga J ${ }^{1}$, Duez $\mathrm{P}^{3}$ and \\ Lumbu Simbi JB ${ }^{4}$ \\ ${ }^{1}$ Laboratoire de pharmacognosie - Faculté des Sciences Pharmaceutiques - Université de Lubumbashi-27, av Kato, \\ Commune Kampemba, Lubumbashi-DR Congo. \\ 2 Service de chimie thérapeutique et analyse des substances naturelles-Faculté des Sciences Pharmaceutiques (UNILU) - \\ 27, av Kato, Commune Kampemba, Lubumbashi-DR Congo. \\ ${ }^{3}$ Service de Chimie Thérapeutique et de Pharmacognosie-Faculté de Médecine -Pharmacie-Université de Mons - 25 \\ Chemin du Champ de Mars 7000 Mons-Belgium. \\ ${ }^{4}$ Laboratoire de Chimie organique - Faculté des Sciences Université de Lubumbashi- 2 av de la maternité, Commune of \\ Lubumbashi -DR Congo.
}

Publication history: Received on 29 October 2020; revised on 17 November 2020; accepted on 19 November 2020

Article DOI: https://doi.org/10.30574/gscbps.2020.13.2.0352

\begin{abstract}
Dialium angolense is used in Bagira for its various medicinal properties particularly in the management of infectious diseases. In this study, the methanol and aqueous extracts of leaves and fruits were evaluated for their in vitro antioxidant and antimicrobial properties and their in vivo toxicity on Cavia porcellus. The major phytochemical classes of extracts were screened using standard in-tube reactions. The antimicrobial study was tested on Candida albicans, Escherichia coli, Salmonella typhi, Staphylococcus aureus and Streptococcus pneumoniae using agar well diffusion and dilution methods, while the antioxidant activity was evaluated by a DPPH assay. For the acute toxicity study, animals (6/group) were orally given in a single dose 5000, 1000 or $15000 \mathrm{mg}$ of extract/kg body weight (BW) then observed for 14 days. In sub-acute toxicity assays, 150 or $300 \mathrm{mg} / \mathrm{kg} \mathrm{BW} /$ day were orally given, and animals observed for 28 days. Total phenolics and total flavonoids contents ranged 1.19 to $1.61 \mathrm{mg}$ GAE.g-1 and 0.45 to $1.01 \mathrm{mg}$ QEg-1, respectively. The extracts presented antioxidant activity with $\mathrm{IC}_{50}$ ranging 4.9 to $6.9 \mu \mathrm{g} / \mathrm{mL}$. The minimal inhibitory concentration (MIC) on tested strains ranged from 1.9 to $500 \mu \mathrm{g} / \mathrm{mL}$ with the aqueous extract of fruits as a most active extract: $\mathrm{MIC}=1.9 \mu \mathrm{g} / \mathrm{mL}$ on $E$. coli and $C$. albicans. No signs of toxicity were noted during the acute and sub-acute toxicity assessments, suggesting a maximal tolerate doses (MDT) and $\mathrm{LD}_{50}>15000 \mathrm{mg} / \mathrm{kg} \mathrm{BW}$. This study highlights the antioxidant and antimicrobial activities of Dialium angolense and suggests that further studies be directed towards the isolation of active compounds.
\end{abstract}

Keywords: Antibacterial; Anti-free radical activity; Flavonoids; Dialium angolense; Phenolics; Toxicity

\footnotetext{
* Corresponding author: Bashige Chiribagula V

Laboratoire de pharmacognosie - Faculté des Sciences Pharmaceutiques - Université de Lubumbashi- 27, av Kato, Commune Kampemba, Lubumbashi-DR Congo.

Copyright (C) 2020 Author(s) retain the copyright of this article. This article is published under the terms of the Creative Commons Attribution Liscense 4.0.
} 


\section{Graphical abstract}

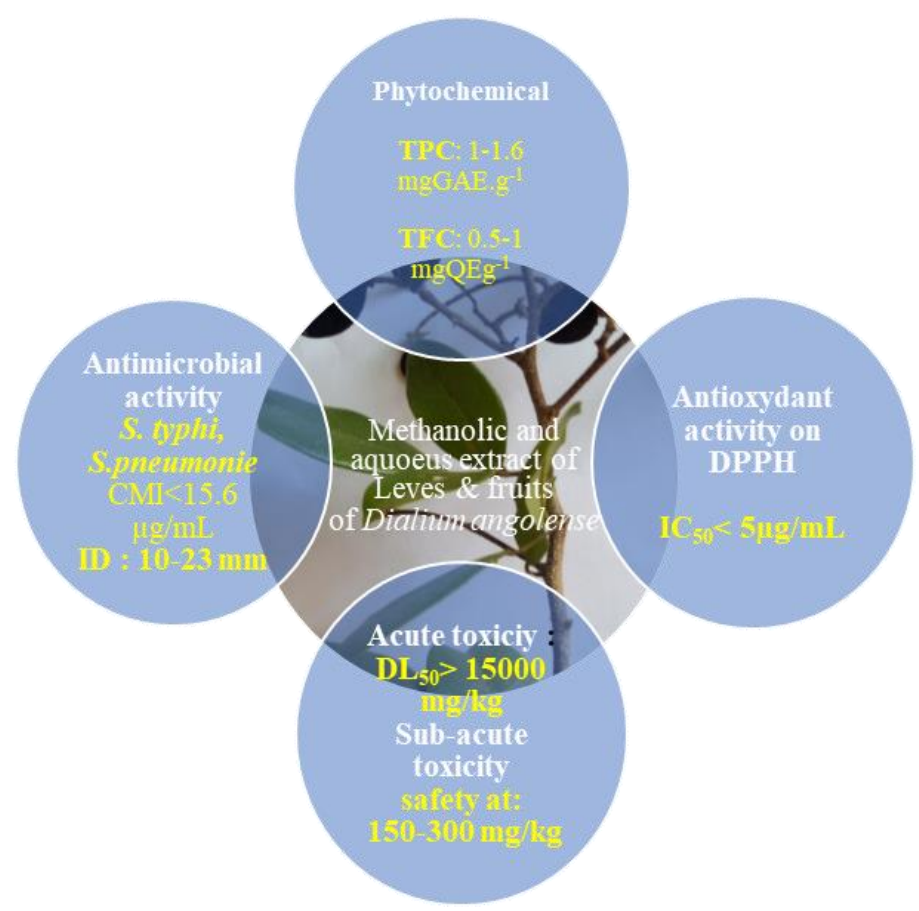

\section{Introduction}

Microbial infections are a major health concern not only because of their high prevalence but also of their high mortality in most African countries like the DR Congo [1-4]. Despite the existence of a varied therapeutic arsenal [5], the emergence of antimicrobial resistances reduces its impact and justifies the need for the research of new active therapeutic substances with various mechanisms of action [6-9]. Rich in secondary metabolites, plants used in traditional medicine have advantages that could offer humanity such expected antimicrobials [10,11]. Several screening studies, carried out in different African regions, have resulted in the isolation and characterization of antimicrobial compounds [12-14]. Several antimicrobial compounds have antioxidant potential [15-17]. That is why, there is currently a tendency to investigate antimicrobial and antioxidant activities as shown by several recent studies carried out on African medicinal plants [18-20]. Despite their reported medicinal properties, indicated by ethnobotanical studies, the pharmacology of the many plants used in traditional African medicine is quite often insufficiently investigated and their safety is mostly unknown. [21,22].

Dialium angolense Welw. ex Oliv., also called Dialium evrardii (Steyaert) belongs to the Fabaceae family, with many local names like Kizimya (Shi) or Cituzo (Havu); is one of those medicinal plants that are not well known. It is a tree of 3 to 12 meters high, endemic in tropical Africa. In DR Congo, the leaves and the fruits are used in the treatment of headaches, fever, gastritis, conjunctivitis, urethritis, amebiasis, malaria, digestive and respiratory diseases. Both organs are edible, the fruits are consumed by humans and the leaves by primates [23,24]. A recent study reported antioxidant and antiplasmodial activities in vitro of aqueous and methanolic extracts of Dialium angolense leaves [25]. Unfortunately, no information has been reported on the antimicrobial potential or less on the toxicity and phytochemical composition of the leaves and fruits of this plant. This study aims to evaluate the antimicrobial activity of aqueous and methanolic extracts of leaves and fruits of Dialium angolense on germs responsible for some digestive, respiratory and nosocomial infections. It also intends to establish its phytochemical profile in secondary metabolites and assess the acute and subacute toxicity of its two organs, on Cavia porcellus.

\section{Material and methods}

\subsection{Plant material and experimental animals}

Leaves and fruits of Dialium angolense were collected on June 2016 from Bagira (2²8'12.9"S; $\left.28^{\circ} 49^{\prime} 18^{\prime \prime} \mathrm{E} ; 2,883.1 \mathrm{~m}\right)$ and was identified at the herbarium of Meise in Belgium (voucher number: BR0000018879285). Healthy Cavia porcellus $(275.5 \pm 5.2 \mathrm{~g})$ were obtained from animals holding unit of the zoo-technology Department of the Faculty of 
Agronomic Sciences, University of Lubumbashi. They were allowed unrestricted access to food for rodents (MIDEMADRC) and water ad libitum.

\subsection{Chemicals and reagents}

Ascorbic acid, 1,1-diphenyl-2- picrylhydrazyl radical (DPPH), ciprofloxacin, fluconazole, gallic acid, methanol, quercetin, and vanillin were obtained from Sigma-Aldrich (USA) and all chemicals and solvents were of analytical grade.

\subsection{Preparation of extracts}

Methanolic extracts (ME) were obtained by macerating $350 \mathrm{~g}$ of coarsely powdered dried vegetal material in $1.5 \mathrm{~L}$ of methanol. After $72 \mathrm{~h}$, the extract was filtered on paper (Whatman, USA) and the residue was macerated twice in a similar manner. The filtrates were combined, concentrated, and dried using a rotary evaporator (Büchi R-210, Switzerland) at $40{ }^{\circ} \mathrm{C}$ under reduced pressure :130-180 mbar (Yield, $12.8 \%, \mathrm{~W} / \mathrm{W}$ ). Aqueous extracts (AE) were prepared according to the protocol used in traditional medicine by decocting $320 \mathrm{~g}$ of the sample in $2 \mathrm{~L}$ of local tap water, boiling for $1 \mathrm{~h}$ in a close recipient and filtration on paper. The extract was lyophilized (Yield, $11.9 \%, \mathrm{~m} / \mathrm{m}$ ). For all tests, each extract was dissolved in its extraction solvent before mixed with the vehicle.

\subsection{Screening for secondary metabolites}

The plant extract was analyzed for the presence of some secondary metabolite including alkaloids, coumarins, flavonoids, saponins, steroids, tannins, terpenoids and phenols, using standard in-tube reactions [26, 27].

\subsection{Determination of total phenolics, flavonoids and tannins contents}

The total phenolics content of each sample was measured by a Folin-Ciocalteu method [28] and expressed as milligrams gallic acid equivalents per gram of dry plant extract (mg GAE/g DE) through a calibration curve gallic acid ( $\mathrm{y}=0.011 \mathrm{x}$ $+0.001, \mathrm{R}^{2}=0.998$; linearity range, $1-200 \mathrm{mg} . \mathrm{L}^{-1}$ ). The total flavonoids content was determined using an aluminum trichloride assay [29] and expressed as milligrams quercetin equivalents per gram of dry plant extract (mg QE.g-1 DE) through the calibration curve of quercetin $\left(y=0.008 \mathrm{x}+0.001, \mathrm{R}^{2}=0.996\right.$; linearity range, 0.1 to $\left.150 \mathrm{mg} / \mathrm{mL}\right)$. The total tannins were determined by a vanillin method [30] and expressed as milligrams gallic acid equivalents per gram of dry plant extract (mg GAE.g-1 DE) through the calibration curve established for gallic acid $\left(y=0.006 x+0.0011, R^{2}=0.997\right.$; linearity range, $1-100 \mathrm{mg}$. $\mathrm{L}^{-1}$ ).

\subsection{Antimicrobial Activity Assay}

Candida albicans ATCC 10231, Escherichia coli ATCC 25922, Salmonella typhi ATCC 14028, Staphylococcus aureus ATCC 6538, and Streptococcus pneumoniae ATCC 49619 were supplied by the Provincial Laboratory of Lubumbashi where the tests were carried out using an agar diffusion method [31]. A broth dilution method was used in triplicates to determine the Minimum Inhibitory Concentrations (MIC) and Minimum Microbicidal Concentrations (MMC) of the extract [32]. The germs used during this study were chosen according to the anti-infectious uses of $D$. angolense in Traditional Congolese Medicine (TCM): E. coli, S. typhi, (for digestive infections), S. aureus (for nosocomial infections) and $S$. pneumonia (for respiratory infections). The measurement of the diameter of inhibition (ID) made it possible to determine the sensitivity of different germs by the diffusion method and the dilution test made it possible to determine the MIC and the MMC. These various parameters made it possible to determine and characterize the antimicrobial activities of the extracts.

For the determination of the sensitivity, in sterile Petri dishes, $20 \mathrm{~mL}$ of Muller-Hinton agar were poured and then left to stand for 20 minutes. After solidification, on each culture medium, $1 \mathrm{~mL}$ of bacterial suspension of $10^{8} \mathrm{CFU} / \mathrm{mL}$ was seeded over the entire surface. Blotting paper discs $(\varnothing=6 \mathrm{~mm})$ were impregnated with a volume of $5 \mu \mathrm{L}$ of extracts $(50$ and $100 \mu \mathrm{g} / \mathrm{mL}$ ) and placed on the surface of the solidified and infected medium. The Petri dishes were then incubated at $37^{\circ} \mathrm{C}$ for $48 \mathrm{~h}$ in the oven. The sensitivity of the germs to the extracts was estimated by measuring the diameter (mm) of the zone of inhibition induced by the different concentrations around the discs and each experiment was repeated three times [33].

Regarding the determination of the MIC, $100 \mu \mathrm{L}$ of each extract at $1 \mathrm{mg} / \mathrm{mL}$ (dissolved in methanol or water depending on the extract) was mixed with $1900 \mu \mathrm{L}$ of the culture medium. Eight successive dilutions of order 2 (from $50 \mu \mathrm{g} / \mathrm{mL}$ to $1.9 \mu \mathrm{g} / \mathrm{mL}$ ) were then carried out for each extract and placed in different aseptic tubes of $5 \mathrm{~mL} ; 1000 \mu \mathrm{L}$ of the standard inoculum was then added to each tube and the mixture was incubated for $24 \mathrm{~h}$ at $37^{\circ} \mathrm{C}$. The growth of the microorganisms was observed visually. The MIC, considered to be the lowest concentration at which the extract prevented the visible growth of bacteria was determined [26]. 
Regarding the determination of the minimum microbicidal concentration (MCM), the sampling was carried out in tubes used for the determination of the MIC. The inoculation was carried out in the Petri dishes on Salmonella-shigella agar (bacteria) or Sabouraud agar (fungi) medium and the incubation was carried out at $37^{\circ} \mathrm{C}$ (bacteria) or $28^{\circ} \mathrm{C}$ (fungi) for $24 \mathrm{~h}$. Microbial growth was checked visually and MMC, defined as the smallest concentration at which the extract prevented the visible growth of microbes (fungi or bacteria) after sub culturing was determined [32].

\subsection{DPPH assay}

Antioxidant activity was evaluated using DPPH method [25, 34]. Briefly, $50 \mu \mathrm{L}$ of extract (or positive control) prepared at different dilutions of order 2 in methanol from a $100 \mu \mathrm{g} / \mathrm{mL}$ solution were interacted with $1950 \mu \mathrm{L}$ of $0.002 \%$ DPPH in a plate 96 wells (Nunc WVR, Germany). After mixing and incubating in the dark for 30 minutes, the solution was read at $492 \mathrm{~nm}$ (Thermo Fisher Scientific Inc., Waltham, USA). The tests were carried out in triplicate and the $0.002 \%$ DPPH solution was used as a negative control. The percentage of antioxidant activity was calculated by the formula:

$\% \mathrm{AAO}=(\mathrm{Ab}-\mathrm{Ae}) \times 100 / \mathrm{Ab}($ Equation 1$)$

Where, $\mathrm{Ab}=$ absorbance measured in the presence of the negative control; $\mathrm{Ae}=$ absorbance measured in the presence of the extract, AAO (\%) = Percentage of inhibition.

\subsection{Toxicological Study}

Acute toxicity was carried out as previously described [35] using, 0 (i.e. vehicle $=$ control), 5000, 10000, 15000 mg/kg BW in single dose (oral administration; 6 animals per group, followed over14 days). For the subacute toxicity study, Cavia porcellus ( 6 animals per group) orally received for 28 days, 0 (i.e. vehicle $=$ control), 150, and $300 \mathrm{mg} / \mathrm{kg} \mathrm{BW} / \mathrm{day}$. During blood collection and serum preparation for biochemical analysis, validated procedures were followed [35]. The activities of alkaline phosphatase (ALP), aspartate transaminase (AST), alanine transaminase (ALT), and the levels of urea and creatinine were determined by colorimetric assays with Labtest $®$ kits (Minas Gerais, Brazil). When evaluating subacute toxicity, we used the dose of $150 \mathrm{mg} / \mathrm{kg}$, corresponding to the dose used in traditional medicine, and double of this dose (300 mg/kg); As for the doses used for the assessment of acute toxicity, we took into account the doses from the preliminary tests following the Organization for Economic Cooperation and Development OECD procedure for which up to $3000 \mathrm{mg} / \mathrm{kg}$ no sign of toxicity was observed.

\subsection{Statistical Analysis}

Values were analyzed using GraphPad Prism 6 (GraphPad Software, La Jolla, USA). Comparisons between different groups were carried out by analysis of variance, ANOVA; a probability level $\mathrm{p}<0.05$ was considered significant.

\subsection{Ethical Approval}

The principles governing the use of laboratory animals as laid out by OECD, Minna Committee on Ethics for Medical and Scientific Research and also existing internationally accepted principles for laboratory animal use and care as contained in the Canadian Council on Animal Care Guidelines and Protocol Review [36] were duly observed. The project proposal and procedures were reviewed and approved by the Department of Pharmacology in the faculty of Pharmaceutical Sciences from the University of Lubumbashi, DR Congo (UNILU/FSP/DPCOL/PT/00/2014).

\section{Results}

\subsection{Chemical screening of Dialium angolense}

The phytochemical screening of Dialium angolense revealed the presence of polyphenols, tannins, terpenoids, flavonoids, coumarins, anthraquinones but the absence of alkaloids and saponins (Table 1).

The highest values in total phenols $\left(1.6118 \pm 0.006 \mathrm{mg} \mathrm{GAEg}^{-1}\right)$, total flavonoids $\left(1.0112 \pm 0.006 \mathrm{mg}^{\mathrm{QE}}\right.$. $\left.\mathrm{g}^{-1}\right)$ and total tannins $\left(0.2830 \pm 0.001{\left.\mathrm{GAE} . \mathrm{g}^{-1}\right)}^{-}\right.$were observed in the methanolic extract of fruits (MEF). Overall, the total flavonoids levels are more than 3 times higher than the total of tannins and the fruit contents are higher $(\mathrm{p}<0.01)$ than leaves (Table 2). 
Table 1 Phytochemical screening of Dialium angolense.

\begin{tabular}{lll}
\hline Phytochemical & Leaves & Fruits \\
\hline Alkaloids & - & - \\
Anthraquinones & + & + \\
Coumarins & + & + \\
Flavonoids & + & + \\
Polyphenols & + & + \\
Saponins & - & - \\
Steroids & + & + \\
Tannins & + & + \\
Terpenoids & + & + \\
\hline egative reaction. Screening carried out by reactions in solution from the powder of the plant drug
\end{tabular}

Table 1 Total polyphenol, flavonoid and tannins contents of extract from Dialium angolense.

\begin{tabular}{llll}
\hline Simple & $\begin{array}{l}\text { Total phenolics } \\
\text { (mg GAEg-1) }\end{array}$ & $\begin{array}{l}\text { Total flavonoids } \\
\text { (mg QE. g-1 }\end{array}$ & $\begin{array}{l}\text { Total tannins } \\
\text { (mg GAE.g-1 }^{-1}\end{array}$ \\
\hline MEL & $1.212 \pm 0.003$ & $0.495 \pm 0.001$ & $0.221 \pm 0.002$ \\
AEL & $1.191 \pm 0.004$ & $0.452 \pm 0.004$ & $0.182 \pm 0.001$ \\
MEF & $1.612 \pm 0.006^{\mathrm{a}}$ & $1.011 \pm 0.006^{\mathrm{a}}$ & $0.283 \pm 0.001^{\mathrm{a}}$ \\
AEF & $1.583 \pm 0.005^{\mathrm{a}}$ & $0.981 \pm 0.008^{\mathrm{a}}$ & $0.243 \pm 0.002^{\mathrm{a}}$ \\
\hline
\end{tabular}

MEL: methanolic leaf extract, AEL: aqueous leaf extract, MEF: methanolic fruit extract, AEF: aqueous fruit extract. The results are expressed as the mean \pm standard deviation. The comparison is made between extracts of the same nature (aqueous extract between them and methanolic extracts between them). The letter presents the level of significance of the difference: a $p<0.01, b p<0.001$

\subsection{Antioxidant activity}

Depending on their IC 50 values, extracts were classified as following: (i) very active if $\mathrm{IC}_{50} \leq 5 \mu \mathrm{g} / \mathrm{mL}$, (ii) active if 5 $\mu \mathrm{g} / \mathrm{mL} \leq \mathrm{IC}_{50} \leq 15 \mu \mathrm{g} / \mathrm{mL}$, (iii) moderately active if $15 \mu \mathrm{g} / \mathrm{mL}<\mathrm{IC}_{50}<50 \mu \mathrm{g} / \mathrm{mL}$, (iv) weakly active if IC $50 \geq 50 \mu \mathrm{g} / \mathrm{mL}$ [25]. The scavenging ability of tested samples showed a concentration-dependent activity. The anti-free radical activity, expressed in the form of $\mathrm{IC}_{50}$, varied between 1.62 and $6.87 \mu \mathrm{g} / \mathrm{mL}$ suggesting that all extract were very actives. In line with their higher content in phenols, flavonoids and tannins, the fruits have an anti-radical power superior to that of the leaves $(\mathrm{p}<0.01)$ and particularly AEF, although less than that of ascorbic acid, used as positive control (Figure 1).
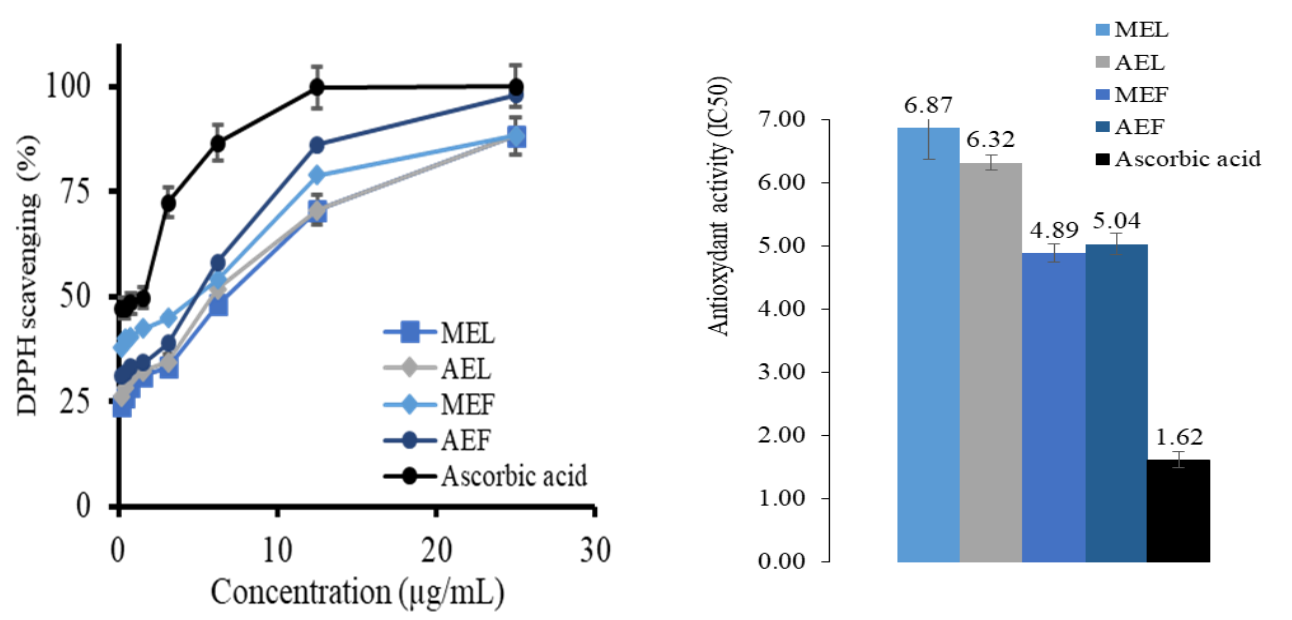

Figure 1 Dialium angolense DPPH radical scavenging activities expressed as percent reduction (a) and as $\mathrm{IC}_{50^{-1}}(\mathrm{~b})$. The results are expressed as the mean $\pm S D, n=5$ 


\subsection{Antimicrobial activity}

\subsubsection{Sensitivity of tested bacteria and fungus}

The microbial sensibility was assessed by the measurement of inhibition diameter (ID) on agar. A microbial strain was considered "sensitive" for ID $\geq 10 \mathrm{~mm}$ [37]. The highest dose-dependent sensitivity was observed by E. coli (ID of AEL is $24.0 \pm 0.2 \mathrm{~mm}$ ). In this study, $S$. pneumoniae and $S$. typhi are the most sensitive microbes in the study with $100 \%$ and $80 \%$ of positive tests, respectively (Table 3 ).

Table 2 Sensitivity of selected microbial strains to Dialium angolense extracts.

Inhibition diameter (mm)

\begin{tabular}{llllll}
\hline Simple & E. coli & S. typhi & $\begin{array}{l}\text { S. pneumoniae } \\
\mathbf{5 0} \boldsymbol{\mu g} / \mathbf{m L}\end{array}$ & S. aureus & C. albicans \\
\hline FLUC & - & - & - & - & $27.3 \pm 0,1$ \\
CIP & $28.0 \pm 0.2$ & $27.0 \pm 0.1$ & $18.0 \pm 0.1$ & $29.0 \pm 0.1$ & $8.0 \pm 0.4$ \\
MEL & $1.2 \pm 0.1$ & $9.1 .0 \pm 0.2$ & $10.1 \pm 0.1$ & $9.0 \pm 0.1$ & $10.0 \pm 0.2$ \\
AEL & $3.0 \pm 0.2$ & $10.0 \pm 0.2$ & $12.0 \pm 0.2$ & $8.0 \pm 0.2$ & $8.0 \pm 0.1$ \\
MEF & $8.0 \pm 0.1$ & $17.0 \pm 0.2$ & $14.0 \pm 0.1$ & $15.0 \pm 0.1$ & $14.0 \pm 0.1$ \\
AEF & $20.0 \pm 0.2$ & $19.0 \pm 0.1$ & $19.0 \pm 0.2$ & $18.0 \pm 0.2$ & $19.0 \pm 0.1$ \\
& & & $\mathbf{1 0 0} \boldsymbol{\mu g} / \mathbf{m L}$ & & \\
MEL & $6.2 \pm 0.2$ & $6.0 \pm 0.2$ & $12.0 \pm 0.2$ & $9.0 \pm 0.2$ & $11.0 \pm 0.2$ \\
AEL & $9.0 \pm 0.2$ & $11.0 \pm 0.1$ & $12.0 \pm 0.2$ & $8.0 \pm 0.2$ & $12.0 \pm 0.2$ \\
MEF & $20.0 \pm 0.1$ & $19.0 \pm 0.1$ & $18.0 \pm 0.2$ & $17.0 \pm 0.2$ & $15.0 \pm 0.2$ \\
AEF & $24.0 \pm 0.2$ & $22.0 \pm 0.1$ & $23.0 \pm 0.2$ & $21.0 \pm 0.2$ & $23.0 \pm 0.1$ \\
\hline
\end{tabular}

MEL: Methanolic extract of leaves, AEL: aqueous extract of leaves, MEF: Methanolic extract of fruits, AEF: aqueous extract of fruits, Values are Mean $\pm \mathrm{SD}, \mathrm{n}=3$, ciprofloxacin (antibacterial positive control), FLUC: Fluconazole (antifungal positive control).

\subsubsection{MIC (Minimum Inhibitory Concentration) and Minimum Microbicidal Concentration (MMC)}

The MIC allowed to categorize the activity of extracts in one of 4 following groups: i) very active extract if $\mathrm{MIC} \leq 5 \mu \mathrm{g} / \mathrm{mL}$, ii) active extract if $5 \mu \mathrm{g} / \mathrm{mL} \leq \mathrm{MIC} \leq 50 \mu \mathrm{g} / \mathrm{mL}$, iii) moderately active extract if $50 \mu \mathrm{g} / \mathrm{mL} \leq \mathrm{MIC} \leq 325 \mu \mathrm{g} / \mathrm{mL}$ and iv) low activity extract if MIC $>325 \mu \mathrm{g} / \mathrm{mL}$ [32]. All extracts were found to be at least active on S. typhi and S. pneumoniae and $\mathrm{AEF}$ was the most active (MIC $=3.9 \mu \mathrm{g} / \mathrm{mL}$ and $7.8 \mu \mathrm{g} / \mathrm{mL}$, respectively) extract; overall the AEF extract was the most active on other strains, E. coli and C. albicans (Table 4).

Table 4 Minimum Inhibitory Concentration (MIC; $\mu \mathrm{g} / \mathrm{mL}$ ) and Minimum Microbicide Concentration (MMC; $\mu \mathrm{g} / \mathrm{mL}$ ) of Dialium angolense extracts.

\begin{tabular}{|c|c|c|c|c|c|c|}
\hline Simple & & E. coli & S. typhi & S. pneumoniae & S. aureus & C. albicans \\
\hline \multirow[t]{3}{*}{ MEL } & MIC & 500 & 7.8 & 15.6 & 500 & 500 \\
\hline & MMC & 500 & 7.8 & 15.6 & 500 & 500 \\
\hline & Effect & $\mathrm{BC}$ & BS & $\mathrm{BC}$ & $\mathrm{BC}$ & $\mathrm{FC}$ \\
\hline \multirow[t]{3}{*}{ AEL } & MIC & 500 & 7.8 & 15.6 & 500 & 125 \\
\hline & MMC & 500 & 3.9 & 3.9 & 500 & 125 \\
\hline & Effect & $\mathrm{BC}$ & BS & BS & $\mathrm{BC}$ & FC \\
\hline \multirow[t]{3}{*}{ MEF } & MIC & 500 & 3.9 & 3.9 & 250 & 31.2 \\
\hline & MMC & 500 & 15.6 & 3.9 & 250 & 31.2 \\
\hline & Effect & $\mathrm{BC}$ & BS & $\mathrm{BC}$ & $\mathrm{BC}$ & FC \\
\hline \multirow[t]{3}{*}{$\mathrm{AEF}$} & MIC & 1.9 & 3.9 & 7.8 & 125 & 1.9 \\
\hline & MMC & 7.8 & 3.9 & 31.2 & 125 & 31.2 \\
\hline & Effect & BS & $\mathrm{BC}$ & BS & $\mathrm{BC}$ & FS \\
\hline
\end{tabular}

MEL: Methanolic extract of leaves, AEL: aqueous extract of leaves, MEF: Methanolic extract of fruits, AEF: aqueous extract of fruits, BS: bactericide, BS: bacteriostatic, FC: fungicide, FS: fungistatic. 


\subsection{Acute and sub-acute toxicities}

\subsubsection{Clinical signs, weight variation, MTD (maximal tolerate dose) and $50 \%$ lethal dose (LD50)}

As for the control group, no sign of acute or sub-acute toxicity was observed in animals following administration of $D$. angolense extracts; there were no significant variations in weight, either for body (Figure 2) or heart, liver, spleen and kidney (Figure 3a-b).

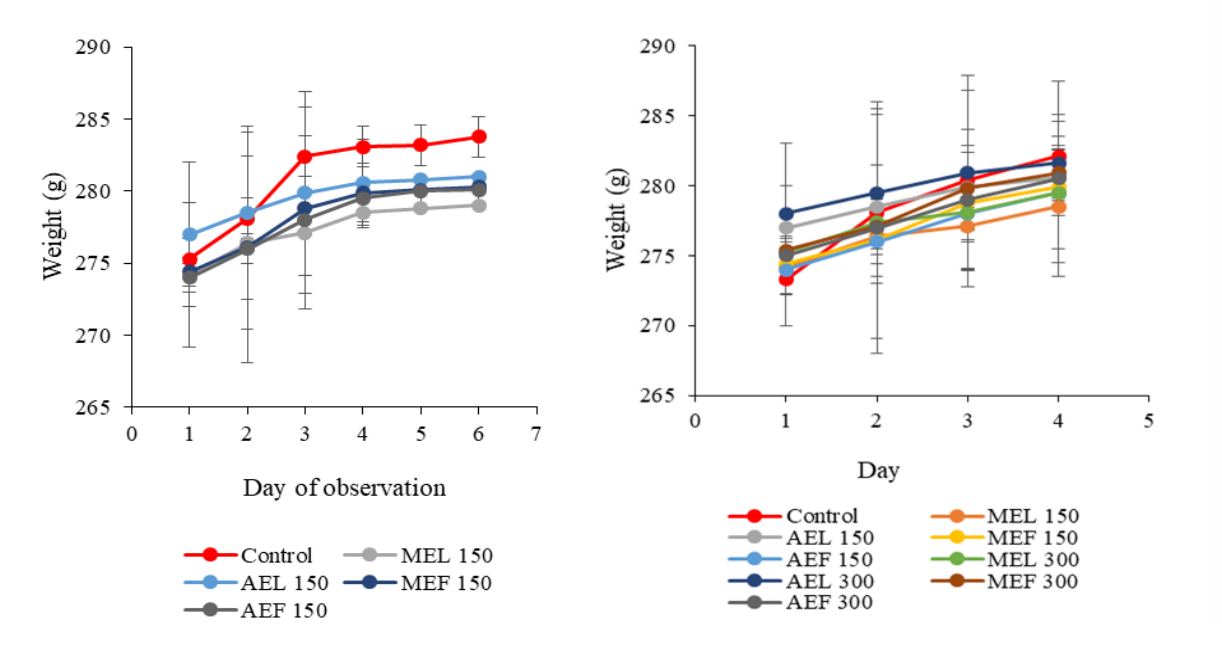

Figure 2 Weight evolution of Cavia porcellus after oral administration of various extracts from the leaves and fruits of D. angolense during the evaluation of acute toxicity (a) with $1.5 \mathrm{~g} / \mathrm{kg}$ and sub-acute (b) with 150 and $300 \mathrm{mg} / \mathrm{kg}$. Results expressed as Mean $\pm S D, n=6$. Weights were taken every 7 days from the first week before intoxication (D-7). AEL: aqueous extract of the leaves, AEF: aqueous extract of the fruits, MEL: methanolic extract of the leaves, MEF: methanolic extract of the fruits. MEL150: the methanolic extract of the leaves administered at a dose of $150 \mathrm{mg} / \mathrm{kg}$ of weight.
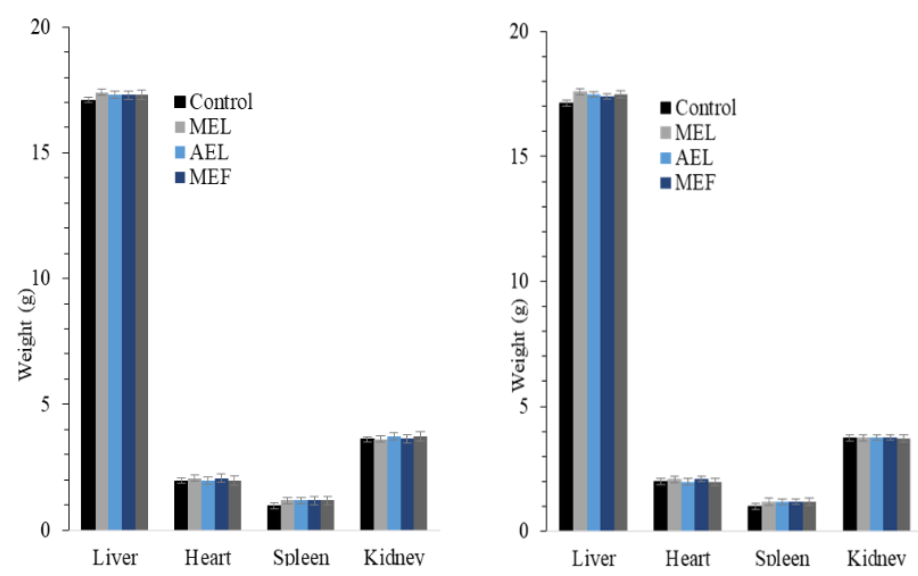

Figure 1 Variation in the weight of the noble organs of Cavia porcellus after oral administration of doses of $150 \mathrm{mg} / \mathrm{kg}$ / d (a) and $300 \mathrm{mg} / \mathrm{kg} / \mathrm{d}$ of extracts of leaves and fruits of Dialium angolense for 28 days. Results expressed as Mean $\pm \mathrm{SD}, \mathrm{n}=6$. AEL: aqueous extract of the leaves, AEF: aqueous extract of the fruits, MEF: methanolic extracts of the leaves, MEL: methanolic extracts of the fruits.

No death was recorded during the experimentation nor any variation in serum biomarkers of the hepatic (transaminases, alkaline phosphatase) and renal (urea, creatinine) functions (Figure $4 \mathrm{c}$-f). The administration of single high doses $(15000 \mathrm{mg} / \mathrm{kg}$ ) or daily therapeutic doses (150 and $300 \mathrm{mg} / \mathrm{kg}$ ) for 28 days of aqueous and methanolic extracts of the leaves and fruits of Dialium angolense does not cause toxicity on Cavia porcellus. The MTD and the LD 50 cannot be estimated from this study but are over $15000 \mathrm{mg}$ extract $/ \mathrm{kg}$. Considering the dosages applied in traditional 
medicine (300 mg of fruits/kg Day or 264 of leaves per day, corresponding to $185 \mathrm{mg} / \mathrm{kg} / \mathrm{j}$ and $147.75 \mathrm{~g} / \mathrm{kg} / \mathrm{day}$ of aqueous extracts, respectively).
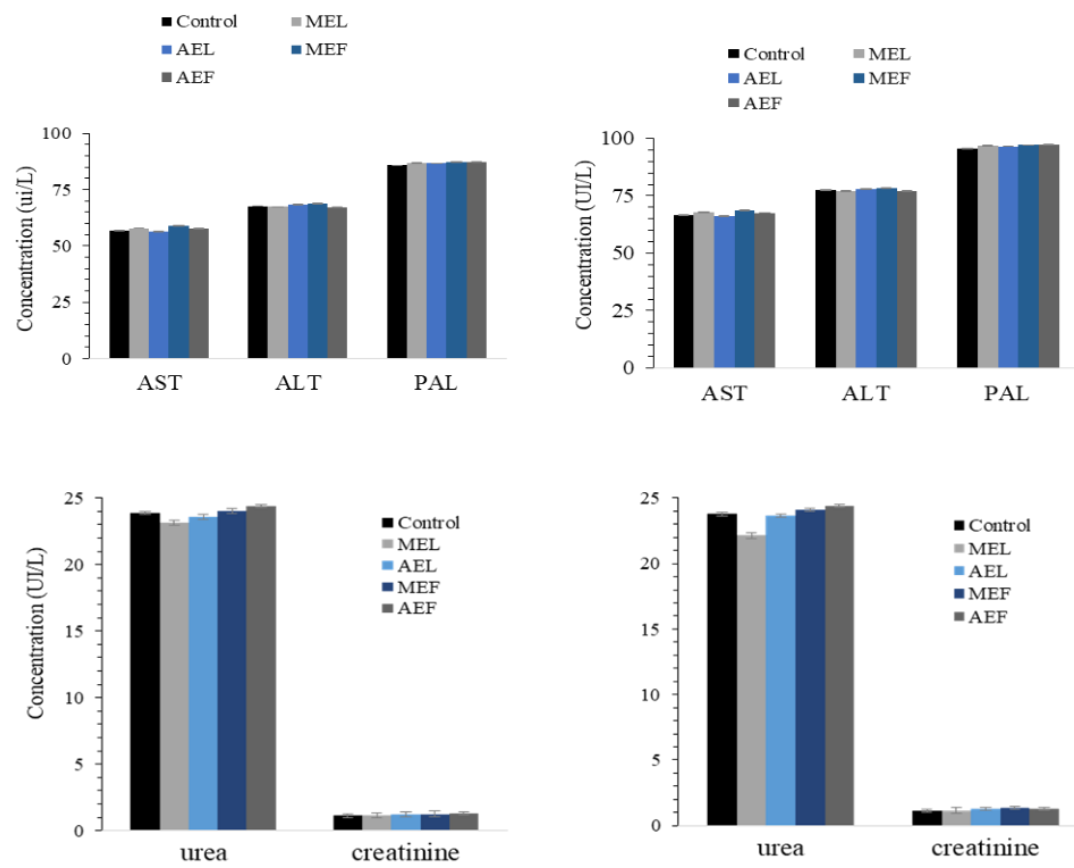

Figure 4 Levels of hepatic (AST, ALT, PAL) and renal (Urea, Creatinine) biomarkers in Cavia porcellus on the 28th day of the experiment, after daily administration of the methanolic (ME) and aqueous (EA) extracts of the leaves (L) and fruits (F) of $D$. angolense at the respective doses of $150 \mathrm{mg} / \mathrm{kg} /$ day (a) and $300 \mathrm{mg} / \mathrm{kg} / \mathrm{day}$ (b). $\mathrm{N}=6$

\subsection{Correlation between antioxidant activity and different content in phenols}

The contents in total phenolics and flavonoids showed a correlation with the measured antioxidant (hydrogendonating) activities; this was particularly the case for flavonoids (Table 5).

Table 5 Correlation between Antioxidant (AOA) and total phenols content of different extracts from $D$ angolense's leaves

\begin{tabular}{lllllll}
\hline & & MEF & AEF & AEL & MEL & R \\
\hline AAO & IC $_{50}{ }^{-1}$ & 0.145 & 0.158 & 0.205 & 0.199 & NA \\
TPC & Concentration & 1.212 & 1.191 & 1.612 & 1.583 & 0.976 \\
& AA0/TPC & 0.120 & 0.133 & 0.127 & 0.125 & NA \\
TFC & Concentration & 0.495 & 0.452 & 1.011 & 0.981 & 0.971 \\
& AA0/TFC & 0.294 & 0.350 & 0.202 & 0.202 & NA \\
TTC & Concentration & 0.221 & 0.182 & 0.283 & 0.243 & 0.787 \\
& AA0/TTC & 0.658 & 0.872 & 0.723 & 0.818 & NA
\end{tabular}

Data expressed as Mean (M), n=3; MEL : Methanolic extract of leaves; AEL: aqueous extracts of leaves; MEF: methanolic extract of fruits; AEF: aqueous extracts of fruits; AOA: antioxidant activity (IC50-1 in $\mu \mathrm{g} / \mathrm{mL}$ ); R : coefficient of correlation with AOA; TPC: Total polyphenol content (mg GAEg-1); TFC: Total Flavonoids contents (mg QE. g-1); TTC: Total tannins contents (mg GAE.g-1).

\subsection{Correlation between Antimicrobial activity and content in different phenols quantified}

A positive correlation was observed between the content of phenols, especially flavonoids, and antimicrobial activity. This correlation was very significant in particular on the strains $S$. typhi $\left(\mathrm{R}_{\mathrm{TPC}}=0.998 ; \mathrm{R}_{\mathrm{TFC}}=0.997\right)$ and . pneumonia $\left(\mathrm{R}_{\mathrm{TPC}}=0.845 ; \mathrm{R}_{\mathrm{TFC}}=0.838\right)$, suggesting that the polyphenols in particular the flavonoids contribute very significantly in the expression of the antimicrobial activity of the different extracts (table 6). 
Table 6 Correlation between Antimicrobial activity (AMA) and total phenols content of different extracts from $D$ angolense's leaves.

\begin{tabular}{lcrrrrrr}
\hline Strain & & MEL & AEL & MEF & AEF & R $_{(\text {TPC }}$ & R $_{(\text {TFC })}$ \\
\hline \multirow{5}{*}{ E. coli } & TPC & 1.212 & 1.191 & 1.612 & 1.583 & & \\
& TFC & 0.495 & 0.452 & 1.011 & 0.981 & & \\
& AMA & 0.002 & 0.002 & 0.002 & 0.526 & 0.534 & 0.543 \\
S. typhi & AMA/TPC & 0.0017 & 0.0017 & 0.0012 & 0.3323 & & \\
& AMA/TFC & 0.0040 & 0.0044 & 0.0020 & 0.5362 & & \\
& AMA & 0.128 & 0.128 & 0.256 & 0.256 & 0.998 & 0.997 \\
S. pneumoniae & AMA/TPC & 0.1056 & 0.1075 & 0.1588 & 0.1617 & & \\
& AMA/TFC & 0.2586 & 0.2832 & 0.2532 & 0.2610 & & \\
AMA aureus & 0.064 & 0.064 & 0.256 & 0.128 & 0.845 & 0.838 \\
& AMA/TPC & 0.0528 & 0.0537 & 0.1588 & 0.0809 & & \\
& AMA/TFC & 0.1293 & 0.1416 & 0.2532 & 0.1305 & & \\
C. albicans & AMA & 0.002 & 0.002 & 0.004 & 0.008 & 0.785 & 0.791 \\
& AMA/TPC & 0.0017 & 0.0017 & 0.0025 & 0.0051 & & \\
& AMA/TFC & 0.0040 & 0.0044 & 0.0040 & 0.0082 & & \\
& AMA & 0.002 & 0.008 & 0.032 & 0.526 & 0.575 & 0.583 \\
\hline
\end{tabular}

Data expressed as Mean (M), n=3; MEL : Methanolic extract of leaves; AEL: aqueous extracts of leaves; MEF: methanolic extract of fruits; AEF: aqueous extracts of fruits; AMA: Antimicrobial activity (MIC50-1 in $\mu \mathrm{g} / \mathrm{mL}$ ); R : coefficient of correlation with AMA; TPC: Total polyphenol content (mg GAEg-1); TFC: Total Flavonoids contents (mg QE. g-1); TTC: Total tannins contents (mg GAE.g-1).

\subsection{Correlation between antioxidant and antimicrobial activity}

Very significant correlation ( $\mathrm{R}>0.87$ ) between antioxidant and antibacterial activity was observed in particular with $S$. typhi, S. pneumoniae, S. aureus and Candida albicans and the relationship between antioxidant activity and antimicrobial (AOA / AMA) for these 4 germs ranged between 0.014 and 2.65 (Table 7).

Table 7 Correlation between Antioxidant (AOA) and antimicrobial activity AMA) of different extracts from $D$. angolense's leaves.

\begin{tabular}{lcrrrrr}
\hline Strains & & MEL & AEL & MEF & AEF & R \\
\hline \multirow{3}{*}{ E. coli } & AAO & 6.87 & 6.32 & 4.89 & 5.04 & \\
& MIC & 500 & 500 & 500 & 1.9 & 0.510 \\
S. typhi & AOA/AMA & 0.014 & 0.013 & 0.010 & 2.650 & \\
& MIC & 7.8 & 7.8 & 3.9 & 3.9 & 0.970 \\
S. pneumoniae & AOA/AMA & 0.881 & 0.810 & 1.254 & 1.291 & \\
& MIC & 15.6 & 15.6 & 3.9 & 7.8 & 0.951 \\
S. aureus & AOA/AMA & 0.441 & 0.405 & 1.254 & 0.646 & \\
& MIC & 500 & 500 & 250 & 125 & 0.917 \\
C. albicans & AOA/AMA & 0.014 & 0.013 & 0.020 & 0.040 & \\
& MIC & 500 & 125 & 31.2 & 1.9 & 0.874 \\
& AOA/AMA & 0.014 & 0.051 & 0.157 & 2.650 &
\end{tabular}

Data expressed as Mean (M), n=3; MEL: Methanolic extract of leaves; AEL: aqueous extracts of leaves; MEF: methanolic extract of fruits; AEF: aqueous extracts of fruits; MIC: minimum inhibitory concentration $(\mu \mathrm{g} / \mathrm{mL})$; R: correlation coefficient; AOA: antioxidant activity.

\section{Discussion}

Given the paucity of information on Dialium angolense, the present study was devoted to the phytochemical screening and evaluation of antioxidant and antibacterial activities as well as to the acute and sub-acute toxicities of leaves and fruits aqueous and methanolic extracts.

Very few studies have reported the phytochemical composition of secondary metabolites of species of the genus Dialium. We show in the leaves of $D$. angolense the presence of polyphenols, particularly flavonoids and tannins, as previously reported for D. guineense Willd and D. indum L.[38,39] and in the fruits flavonoids, saponins, and steroids as reported in D. guineense [40,41]. The fruits of $D$. angolense have higher flavonoid and tannin contents than $D$. indum [41, 
42] but lower than D. guineense [43,44]. There is a need to conduct an extensive phytochemical study of the thirty or so species accepted in this genus [45] to determine whether the flavonoids and/or tannins could constitute chemotaxonomic markers.

The antioxidant activity on DPPH, expressed as $\mathrm{IC}_{50}$ in $\mu \mathrm{g} / \mathrm{mL}$, of several species of the genus Dialium is reported in the literature, D. indum, $181.6 \pm 0.4$ [42,46], D. guineense, $50.2 \pm 0.2$ [47], D. corbisieri Staner, $14.4 \pm 0.1$, D. gossweileri Baker F., > 500 [48], and D. cochinchinense Pierre, $65.0 \pm 0.1$ [49]. The results of this study suggest that $D$. angolense $\left(\mathrm{IC}_{50}=4.9\right.$ $\pm 0.2 \mu \mathrm{g} / \mathrm{mL}$ ) has the highest antioxidant activity compared to the species mentioned above. This interesting antioxidant activity observed in $D$. angolense would be linked to the presence of phenolic compounds mainly flavonoids (Table 5); this is in line with previous studies that attest the antioxidant activity of flavonoids [50-54].

According to the correlation between antioxidant activity and different content in phenols. In this study, there are significant differences between extracts, indicating that the quality of polyphenols/flavonoids in the extract is certainly more important than their content [55]. This is confirmed by Vasco et al. [56] who states that the correlation depends on the extraction solvent, the hydrophilicity of the compounds, the sample, and the type of phenolic compounds. By evidence, not all antioxidant characteristics are assessed by the test performed here; notably, the ability to quench in vivo oxidative damage and lipid peroxidation largely depends on the lipophilicity of the compounds (phenols, tocopherols, carotenoids, and flavonoid aglycones) and the chelation of metals: ascorbic acid, tannins, flavonoid aglycones and glycosides [57].

The antibacterial activity of $D$. angolense fruits is higher compared D. guineense aqueous extract on $E$. coli (MIC = 225 $\mathrm{mg} / \mathrm{mL}$ ), S. typhi (150 mg/mL), S. pneumoniae $(\mathrm{mg} / \mathrm{mL})$ and S. aureus (225 mg/mL) [58]. It is more active than Dialium corbisieri Staner, aqueous extract on $E$. coli (ID $=0$ and $11 \mathrm{~mm})$, S. aureus (ID $=0$ and $10 \mathrm{~mm})$, C. albicans (ID $=0$ and 10 $\mathrm{mm}$ ) [48]. It is likely that the polyphenolic compounds, and particularly flavonoids [59-61], would be both responsible for antioxidant and antibacterial activities of leaves and fruits of $D$. angolense. The antimicrobial activity of flavonoids has previously been demonstrated [62-64] and several antimicrobial mechanisms of compounds in these groups have been demonstrated [59]. It has been established that flavonoids aggravate microorganisms in various ways including to form a complex with the cell wall components and consequently inhibit further adhesions and the microbial growth [65], adhesion to and invasion of hosts by Gram-positive bacteria [66], interaction with liposomes [67], eradication of biofilm bacteria [68] or inhibition of the DNA, RNA and proteins bacterial synthesis [69].

All studied extracts showed a particularly interesting antibacterial activity on S. typhi, justifying the use of $D$. angolense against a condition identified as "typhoid fever" in traditional medicine [23]. This activity is particularly interesting since co-infections Plasmodium falciparum - S. typhi are commonly reported in Bukavu city, as well as elsewhere [70]. As, in the region, the plant is also used as an antimalarial [23] its use may have various benefits.

In this study, it have been established a correlation between antioxidant and antimicrobial activity (Table 7). These results agree with the previous literature where it has been established a correlation between the antioxidant and antimicrobial activity of some plant extracts [71-73]. This correlation would probably be linked to the presence of polyphenols quantified in the plant during this study, as suggested by previous work [74, 75].

Many plants used in traditional medicine with both antioxidant and antimicrobial potential like Punica granatum L., Lythraceae [76], Feijoa sellowiana (0.Berg) 0.Berg, Myrtaceae [77] , Xylopia aethiopica (Dunal) A.Rich., Annonaceae [78], Zingiber officinale Roscoe, Zingiberaceae[79] or Fagaropsis hildebrandtii (Engl.) Milne-Redh., Rutaceae [80], for which $\mathrm{LD}_{50}$ were estimated $\geq 2000 \mathrm{mg} / \mathrm{kg}$ body weight in acute toxicity, present sub-acute toxicity in rodent animal models. By contrast, the methanolic and aqueous extracts of the leaves and fruits of Dialium angolense seem quite innocuous, with $\mathrm{LD}_{50}$ estimated over $15000 \mathrm{mg}$ extract/ $\mathrm{kg}$ and no signs of sub-acute toxicity, hepatic or renal, observed on Cavia porcellus at daily doses of 150 and $300 \mathrm{mg} / \mathrm{kg}$, thus highlighting a probably safe therapeutic use of this plant.

\section{Conclusion}

This study highlights for the first time the antioxidant and antibacterial activities as well as an absence of sub-acute toxicity of the leaves and fruits of $D$. angolense, while pointing to the role of its polyphenols, especially flavonoids. It thus supports the traditional use of this medicinal plant and opens the way to a bio-guided-isolation of these antioxidant and antimicrobial compounds. 


\begin{abstract}
Abbreviations
AEF: Aqueous extracts of fruits; AEL: Aqueous extracts of leaves; ALP: Alkaline phosphatase; ALT: Alanine transaminase; AMA: Antimicrobial activity; AOA: Antioxidant activity; AST: Aspartate transaminase; CFU: Colony Making Unit; CIP: Ciprofloxacin; D-7: 7 day before the experimentation; DE: Dry extract; DPPH: 1,1 diphenyl-2picrylhydrazyl radical; FLUC: Fluconazole; GAE: Gallic acid equivalents; ID: Diameter of inhibition ; LD 5 : 50 \%Lethal dose ; MDT: Maximal dose tolerate; MEF: Methanol extract fruits; MEF: Methanolic extract of fruits; MEL150: Group who received $150 \mathrm{mg} / \mathrm{kg}$ of dose; MIC: Minimum inhibitory concentration; MMC: Minimum Microbicidal Concentrations; OECD: Organization for Economic Cooperation and Development; QE: Quercetin equivalents; TFC : Total flavonoid content; TPC : Total phenols content
\end{abstract}

\title{
Compliance with ethical standards
}

\section{Acknowledgments}

The authors sincerely thank ARES CCD for the funding which made it possible to carry out this study.

\section{Disclosure of conflict of interest}

The authors declare that they have no known competing financial interests or personal relationships that could have appeared to influence the work reported in this paper.

\section{Author contributions}

Conceptualization, Data curation, Formal analysis, Funding acquisition, Investigation, Methodology, Software and Writing - original draft: Bashige Chiribagula valentin, Supervision: Bakari Amuri Salvius, Okusa Ndjolo Philippe, Writing - review \& editing: Bakari Amuri Salvius, Okusa Ndjolo Philippe, Kahumba Byanga Joh; Pierre Duez; Lumbu Simbi JeanBaptiste.

\section{References}

[1] Mbuyi-kalonji L, Barbe B, Nkoji G, Madinga J, Roucher C, Linsuke S, et al. Non-typhoidal Salmonella intestinal carriage in a Schistosoma mansoni endemic community in a rural area of the Democratic Republic of Congo. PLoS Negl Trop Dis. 2020; 14(2): 1-15.

[2] Mbaye R, Gebeyehu R, Hossmann S, Mbarga N, Bih-Neh E, Eteki L, et al. Who is telling the story? A systematic review of authorship for infectious disease research conducted in Africa, 1980-2016. BMJ Glob Heal. 2019; 4(5): $1-10$.

[3] Talisuna AO, Okiro EA, Yahaya AA, Stephen M, Bonkoungou B, Musa EO, et al. Spatial and temporal distribution of infectious disease epidemics, disasters and other potential public health emergencies in the World Health Organisation Africa region, 2016-2018. Global Health. 2020; 16(1): 1-12.

[4] Lupande-Mwenebitu D, Baron SA, Nabti LZ, Lunguya-Metila O, Lavigne J-P, Rolain J-M, et al. Current status of resistance to antibiotics in Democratic Republic of Congo: a Review. Sensors Actuators B Chem. 2019; 127065.

[5] Koulenti D, Song A, Ellingboe A, Abdul-aziz MH, Harris P, Gavey E, et al. Infections by multidrug-resistant Gramnegative Bacteria: What' s new in our arsenal and what's in the pipeline? Int J Antimicrob Agents. 2019; 53(3): 211-224.

[6] Bunduki GK, Katembo J-LM, Kamwira, Soly I. Antimicrobial resistance in a war-torn country: Lessons learned in the Eastern Democratic Republic of the Congo. One Heal. 2019; 9: 100-120.

[7] Jernigan JA, Hatfield KM, Wolford H, Nelson RE, Olubajo B, Reddy SC, et al. Multidrug-resistant bacterial infections in U.S. hospitalized patients, 2012-2017. N Engl J Med. 2020; 382(14): 1309-1319.

[8] Pacios O, Blasco L, Bleriot I, Fernandez-Garcia L, Bardanca, Mónica González Ambroa A, López M, et al. Strategies to Combat Multidrug-Resistant and Persistent Infectious Diseases. Antibiotics. 2020; 9(65): 1-20.

[9] Cock IE, Selesho MI, Vuuren SF Van. A review of the traditional use of southern African medicinal plants for the treatment of malaria. J Ethnopharmacol. 2019; 245: 12176. 
[10] Ginovyan M, Petrosyan M, Trchounian A. Antimicrobial activity of some plant materials used in Armenian traditional medicine. BMC Complement Altern Med. 2017; 17(1): 1-9.

[11] Cheesman MJ, Ilanko A, Blonk B, Cock IE. Developing New Antimicrobial Therapies: Are Synergistic Combinations of Plant Extracts/Compounds with Conventional Antibiotics the Solution? Pharmacogn Rev. 2018; 1(2): 8-15.

[12] Anand U, Jacobo-Herrera N, Altemimi A, Lakhssassi NA. comprehensive review on medicinal plants as antimicrobial therapeutics: Potential avenues of biocompatible drug discovery. Metabolites. 2019; 9(11): 1-13.

[13] Dandawate P, Padhye S, Schobert R, Biersack B. Discovery of natural products with metal-binding properties as promising antibacterial agents. Expert Opin Drug Discov. 2019; 14(6): 563-576.

[14] Mai P-Y, Levasseur M, Buisson D, Touboul D, Eparvier V. Identification of Antimicrobial Compounds from. Plants. 2017; 9(47): 222-231.

[15] Farahmandfar R, Esmaeilzadeh Kenari R, Asnaashari M, Shahrampour D, Bakhshandeh T. Bioactive compounds, antioxidant and antimicrobial activities of Arum maculatum leaves extracts as affected by various solvents and extraction methods. Food Sci Nutr. 2019; 7(2): 465-475.

[16] Rodrigues AB, De Almeida-Apolonio AA, Alfredo TM, Da Silva Dantas FG, Campos JF, Cardoso CAL, et al. Chemical composition, antimicrobial activity, and antioxidant activity of Ocotea minarum (Nees \& Mart.) mez. Oxid Med Cell Longev. 2019; 1-14.

[17] Yahia Y, Benabderrahim MA, Tlili N, Bagues M, Nagaz K. Bioactive compounds, antioxidant and antimicrobial activities of extracts from different plant parts of two Ziziphus Mill. species. PLoS One. 2020; 15(5): 1-16.

[18] Martelli G, Giacomini D. Antibacterial and antioxidant activities for natural and synthetic dual-active compounds. Eur J Med Chem. 2018; 158: 91-105.

[19] Ahmed AS, Moodley N, Eloff JN. Bioactive compounds from the leaf extract of Bauhinia galpinii (Fabaceae) used as antidiarrhoeal therapy in southern Africa. South African J Bot. 2019; 126: 345-353.

[20] Denev P, Číž M, Kratchanova M, Blazheva D. Black chokeberry (Aronia melanocarpa) polyphenols reveal different antioxidant, antimicrobial and neutrophil-modulating activities. Food Chem. 2019; 284(1): 108-117.

[21] Zakariya I, Ifezouane J, Addaoui A, Skalli S, Bouslimane Y. Evaluation of the therapeutic and toxicological knowledge of herbalists on the most notified plants in the poison control and pharmacovigilance center of Morocco. J Pharmacogn Phyther. 2018; 10(8): 126-132.

[22] Ng'uni T, Klaasen JA, Fielding BC. Acute toxicity studies of the South African medicinal plant Galenia africana. Toxicol Reports. 2018; 5(8): 813-818.

[23] Bashige CV, Bakari AS, Ndjolo PO, Kahumba BJ, Duez P, Lumbu SJ. Ethnobotanical study of plants used as antimalarial in traditional medicine in Bagira in Eastern RD Congo. J Pharmacogn Phytochem. 2020; 9(4): 1-14.

[24] Bashige VC, Bakari SA, Okusa PN, Kahumba JB, Lumbu JS. Potential nutrition of leaves and fruits of Dialium Angolense Welw. Ex Oliv. (Fabaceae) an antimalarial plant from the Eastern of DR Congo. Int J Adv Res. 2020; 8(06): 336-345.

[25] Bashige C valentin, Bakari AS, Okusa N, Kahumba BJ, Duez P, Lumbu SJ-B. Antiplasmodial , inhibitor of hemozoin synthesis and antioxidant activities of some plants used as antimalarial drugs in Bagira ( DR Congo ). Int J Pharmacogn Clin Res. 2020; 2(1): 1-8.

[26] Bashige CV, Bakari AS, Numbi IE, Kalonda ME, Ndjolo OP, Kahumba B joh, et al. Criblage Phytochimique et activité antimicrobienne de sept fleurs comestibles utilisées en médecine traditionnelle à Lubumbashi ( RDC ). J Appl Biosci. 2018; 124: 12455-12467.

[27] Babakura M, Usman H, Gaidam YA, Halima UA, Fulata AM. Preliminary Phytochemical Screening , Analgesic and Anti-inflammatory Effects of the Hydroethanol and n -Hexane Leaf Extracts of Maytenus senegalensis Lam . Excell . ( Celestraceae ). South Asian Res J Nat Prod. 2019; 2(1): 1-9.

[28] Fu L, Xu BT, Gan RY, Zhang Y, Xu XR, Xia EQ, et al. Total phenolic contents and antioxidant capacities of herbal and tea infusions. Int J Mol Sci. 2011; 12(4): 2112-2124.

[29] Koolen HHF, da Silva FMA, Gozzo FC, de Souza AQL, de Souza ADL. Antioxidant, antimicrobial activities and characterization of phenolic compounds from buriti (Mauritia flexuosa L. f.) by UPLC-ESI-MS/MS. Food Res Int. 2013; 51(2): 467-473. 
[30] De Britto Policarpi P, Turcatto L, Demoliner F, Ferrari RA, Bascuñan VLAF, Ramos JC, et al. Nutritional potential, chemical profile and antioxidant activity of Chichá (Sterculia striata) nuts and its by-products. Food Res Int. 2018; 106: 736-744.

[31] Adeyemi AI, Vincent OI, Olujenyo OM. Phytochemical screening and antifungal activity of Chromolaena odorata extracts against isolate of Phytophthora megakarya using agar-well diffusion method. Asian J Med Biol Res. 2018; 4(1): 7-13.

[32] Bashige CV, Bakari AS, Okusa PN, Kalonda EM, Lumbu JBS. Criblage phytochimique et activité antimicrobienne de six rhizomes comestibles utilisés en médecine traditionnelle à Lubumbashi (RDC). Int J Biol Chem Sci. 2020; 14(4): 1367-1380.

[33] Khomarlou N, Aberoomand-Azar P, Lashgari ardalan P, Tebyanian H, Hakakian A, Ranjbar R, et al. Essential oil composition and in vitro antibacterial activity of Chenopodium album subsp. Striatum. Acta Biol Hung. 2018; 69(2): 144-155.

[34] Shekhar TC, Anju G. Antioxidant Activity by DPPH Radical Scavenging Method of Ageratum conyzoides Linn. Leaves. Am J Ethnomedicine. 2014; 1(4): 244-249.

[35] Rasekh HR, Nazari P, Kamli-Nejad M, Hosseinzadeh L. Acute and subchronic oral toxicity of Galega officinalis in rats. J Ethnopharmacol. 2008; 116(1): 21-26.

[36] (CCAC) TCC on AC. CCAC guidelines on : animal use protocol review. 1997; 3: 11.

[37] Ouattara K, Doumbia I, Touré A, Djaman AJ, Coulibaly A. Activité antibactérienne des extraits des feuilles de Morinda morindoides (Morinda, Rubiaceae) sur Staphylococcus aureus et Pseudomonas aeruginosa. Phytothérapie. 2013; 11(3): 172-177.

[38] Besong EE, Balogun ME, Djobissie SFA, Obu DC, Obimma JN. Medicinal and Economic Value of Dialium Guineense. Afr J Biomed Res. 2016; 19(5): 163-170.

[39] Adjileye RA, Amoussa AMO, Lagnika L, Trema orientalis L, Dialium guineense Wild. used to manage hypertension in Benin: Phytochemical study and antioxidant activity. J Med Plants Stud. 2019; 7(3): 43-48.

[40] Okeke NC, Udeani TK, Onyebuchi UL. Wound-healing and antimicrobial properties of dichloromethane fraction of Dialium guineense (Wild) fruit coat. Res Pharm Sci. 2016; 11(3): 219-226.

[41] Ahodegnon k. D, Martial G, Reine BS, Kanfon RE telle, Chabin B, Agbangnan DCP, et al. Biochemical Profile And Antioxidant Activity of Parkia Biglobosa and Tamarindus Indica fruits acclimated In Benin. Int J Adv Res. 2018; 6(11): 702-711.

[42] Osman MF, Hassan NM, Khatib A, Tolos SM. Antioxidant Activities of Dialium indum L. Fruit and Gas Chromatography-Mass Spectrometry (GC-MS) of the Active Fractions. Antioxidants. 2018; 7(11): 154.

[43] Ogu GI, Ezeadila J, Ehiobu JM. Antioxidant and antimicrobial activities of Dialium guineense (Willd) leaf extract. Pharm Pharmacol Res. 2013; 1(1): 1-7.

[44] Adeleye AO, Ajiboye TO, Iliasu GA, Abdussalam FA, Balogun A, Ojewuyi OB, et al. Phenolic extract of Dialium guineense pulp enhances reactive oxygen species detoxification in aflatoxin B1 hepatocarcinogenesis. J Med Food. 2014; 17(8): 875-885.

[45] Azani N, Babineau M, Bailey CD, Banks H, Barbosa AR, Pinto RB, et al. A new subfamily classification of the leguminosae based on a taxonomically comprehensive phylogeny. Taxon. 2017; 66(1): 44-77.

[46] Bamikole AO, Ibidun 00, Ibitayo OA, Bolaji AO, Idowu OI, Damilola BB, et al. Evaluation of antioxidant potentials of different solvent-fractions of Dialium indium (African Black Velvet Tamarind) Fruit Pulp - In Vitro. Potravinarstvo. 2018; 12(1): 70-79.

[47] Oluwole-Banjo A. Phytochemical and antioxidant properties of pulp, seed, leaf and stem bark of velvet tamarind (Dialium guineense) plant. J Underutilized Legum. 2019; 1(1): 159-168.

[48] Maloueki U, Kapetshi J, Kabena NO, Ndimbo KS, Ngbolua KJ, Bekeli N, et al. Activités antimicrobiennes et antioxydantes des extraits aqueux totaux des fruits de Dialium corbisieri et Dialium gossweilerii ( FabaceaeCaesalpinioideae ), consommés par les bonobos , Bolobo , République Démocratique du Congo. 9April 2015; 633642.

[49] Bui L, Nguyen Q, Dao L, Nguyen H, Lam M, Hoang C. Evaluation of antimicrobial, antioxidant and cytotoxic activities of Dialium cochinchinensis Seed Extract. Indian J Pharm Sci. 2019; 81(5): 975-980. 
[50] Ravanfar SA, Karimi E, Mehrabanjoubani P, Ebrahimi M. Enhancement of phenolic and flavonoids compounds, antioxidant and cytotoxic effects in regenerated red cabbage by application of Zeatin. Nat Prod Res. 2020; 34(6): 898-902.

[51] Zhang X, Wang X, Wang M, Cao J, Xiao J, Wang Q. Effects of different pretreatments on flavonoids and antioxidant activity of Dryopteris erythrosora leave. PLoS One. 2019; 14(1): 1-17.

[52] Gu ZY, Feng CY, Li SS, Yin DD, Wu Q, Zhang L, et al. Identification of flavonoids and chlorogenic acids in elm fruits from the genus Ulmus and their antioxidant activity. J Sep Sci. 2019; 42(18): 2888-2899.

[53] Tine Y, Diallo A, Ndoye I, Yang Y, Renucci F, Guèye RS, et al. Flavonoid Compounds from Zanthoxylum leprieurii Guill. et Perr (Rutaceae) Extracts and their antioxidant activity against ABTS•+. J Drug Deliv Ther. 2020; 10(2-S): 120-124.

[54] Xu QN, Zhu D, Wang GH, Lin T, Sun CL, Ding R, et al. Phenolic glycosides and flavonoids with antioxidant and anticancer activities from Desmodium caudatum. Nat Prod Res. 2020; 0(0): 1-8.

[55] Guendouze-Bouchefa N, Madani K, Chibane M, Boulekbache-Makhlouf L, Hauchard D, Kiendrebeogo M, et al. Phenolic compounds, antioxidant and antibacterial activities of three Ericaceae from Algeria. Ind Crops Prod. 2015; 70: 459-466.

[56] Vasco C, Ruales J, Kamal-Eldin A. Total phenolic compounds and antioxidant capacities of major fruits from Ecuador. Food Chem. 2008; 111(4): 816-823.

[57] Bramorski A, Cherem A da R, Marmentini CP, Torresani J, Mezadri T, Costa A de AS. Total polyphenol content and antioxidant activity of commercial Noni (Morinda citrifolia L.) juice and its components. Brazilian J Pharm Sci. 2010; 46(4): 652-656.

[58] Ajiboye AE, Babatunde SK, Adedayo MR, Busayo AI, Odaibo DA, Ihesie IU. Antibacterial activity of the seed of Dialium guineense against selected enteric bacteria. Covenant J Phys Life Sci. 2018; 6(2): 1-10.

[59] Farhadi F, Khameneh B, Iranshahi M, Iranshahy M. Antibacterial activity of flavonoids and their structure-activity relationship: An update review. Phyther Res. 2019; 33(1): 13-40.

[60] Xu F, Cao S, Wang C, Wang K, Wei Y, Shao X, et al. Antimicrobial activity of flavonoids from Sedum aizoon L. against Aeromonas in culture medium and in frozen pork. Food Sci Nutr. 2019; 7(10): 3224-3232.

[61] Abdu OH, Saeed AAM, Fdhel TA. Polyphenols/flavonoids analysis and antimicrobial activity in Pomegranate polyphenols extracts. Electron J Univ Aden Basic Appl Sci. 2020; 1(1): 14-19.

[62] Bylka W, Matlawska I, Pilewski N. Natural flavonoids as antimicrobial agents. Jana. 2004; 7(2): 9-16.

[63] Cushnie TPT, Lamb AJ. Antimicrobial activity of flavonoids. Int J Antimicrob Agents. 2005; 26(5): 343-356.

[64] Górniak I, Bartoszewski R, Króliczewski J. Comprehensive review of antimicrobial activities of plant flavonoids. Phytochem Rev. 2019; 18(1): 241-272.

[65] Edziri H, Mastouri M, Mahjoub MA, Mighri Z, Mahjoub A, Verschaeve L. Antibacterial, antifungal and cytotoxic activities of two flavonoids from Retama raetam flowers. Molecules. 2012; 17(6): 7284-7293.

[66] Yang H, Wang M, Yu J, Wei H. Antibacterial activity of a novel peptide-modified lysin against Acinetobacter baumannii and Pseudomonas aeruginosa. Front Microbiol. 6 DEC 2015; 1-9.

[67] Echeverría J, Opazo J, Mendoza L, Urzúa A, Wilkens M. Structure-activity and lipophilicity relationships of selected antibacterial natural flavones and flavanones of Chilean flora. Molecules. 2017; 22(4): 1-15.

[68] Al-Shabib NA, Husain FM, Ahmad I, Khan MS, Khan RA, Khan JM. Rutin inhibits mono and multi-species biofilm formation by foodborne drug resistant Escherichia coli and Staphylococcus aureus. Food Control. 2017; 79: 325332.

[69] Dzoyem JP, Hamamoto H, Ngameni B, Ngadjui BT, Sekimizu K. Antimicrobial action mechanism of flavonoids from Dorstenia Species. Drug Discov Ther. 2013; 7(2): 66-72.

[70] Bashige CV, Manya MH, Bakari AS, Sangwa KG, Kahumba BJ, Pierre D, et al. Prévalence et caractéristiques de l'automédication chez les étudiants de 18 à 35 ans résidant au campus de la Kasapa de l'Université de Lubumbashi. Pan Afr Med J. 2015; 21: 77.

[71] Fazeli-Nasab B, Rahnama M, Mazarei A. Correlation between antioxidant activity and antibacterial activity of nine medicinal plant extracts. J Maz Univ Med Sci. 2017; 27(149): 63-78. 
[72] Vieitez I, Maceiras L, Jachmanián I, Alborés S. Antioxidant and antibacterial activity of different extracts from herbs obtained by maceration or supercritical technology. J Supercrit Fluids. 2018; 133(8): 58-64.

[73] Desta ZY, Cherie DA. Determination of antioxidant and antimicrobial activities of the extracts of aerial parts of Portulaca quadrifida. Chem Cent J. 2018; 12(1):1-6.

[74] Bahri-Sahloul R, Ben Fredj R, Boughalleb N, Shriaa J, Saguem S, Hilbert JL, et al. Phenolic composition and antioxidant and antimicrobial activities of extracts obtained from Crataegus azarolus L. var. aronia (Willd.) Batt. Ovaries calli. J Bot. 2014; 1-8.

[75] Todorovic V, Milenkovic M, Vidovic B, Todorovic Z, Sobajic S. Correlation between Antimicrobial, Antioxidant Activity, and Polyphenols of Alkalized/Nonalkalized Cocoa Powders. J Food Sci. 2017; 82(4): 1020-1027.

[76] Setiadhi R, Sufiawati I, Zakiawati D, Nur N, Hidayat W, Firman DR. Evaluation of antibacterial activity and acute toxicity of pomegranate (Punica granatum L .) seed ethanolic extracts in swiss webster mice. J Dentomaxillofacial Sci. $2017 ; 2(2): 119-123$.

[77] Mosbah H, Louati H, Ali M, Chahdoura H, Snoussi M, Flamini G, et al. Industrial Crops \& Products pharmacological activities of Feijoa sellowiana leaves growing in Tunisia. Ind Crop Prod. 2018; 112: 521-531.

[78] Yusuf AA, Lawal B, Yusuf MA, Omonije YO, Adejoke AO, Raji FH, et al. Free radical scavenging, antimicrobial activities and effect of sub-acute exposure to Nigerian Xylopia aethiopica seed extract on liver and kidney. Iran J Toxicol. 2018; 12(3): 51-58.

[79] Yusuf AA, Lawal B, Abubakar AN, Berinyuy EB, Omonije YO, Umar SI, et al. In-vitro antioxidants, antimicrobial and toxicological evaluation of Nigerian Zingiber officinale. Clin Phytoscience. 2018; 4(12): 2-9.

[80] Muia BM, Mbaria JM, Kanja LW, Gitahi N, Okumu PO, Okumu MO. Acute and sub-acute toxicity study of the root extracts of Fagaropsis hildebrandtii in mice and evaluation of their antimicrobial effects. F1000Research. 2020; 8(1444): 1-22. 